\title{
Ökse Otu (Viscum album L.)'nun Yem Kalitesinin Belirlenmesi
}

\author{
Yasin Emre ÖZTÜRK ${ }^{1}$, Erdem GÜLÜMSER ${ }^{1 *}$, Hanife MUT ${ }^{1}$, Medine ÇOPUR DOĞRUSÖZ ${ }^{2}$, \\ Uğur BAŞARAN ${ }^{2}$ \\ ${ }^{\prime}$ Bilecik Şeyh Edebali Üniversitesi, Ziraat ve Doğa Bilimleri Fakültesi, Tarla Bitkileri Bölümü, Bilecik, TÜRKIYE \\ ${ }^{2}$ Yozgat Bozok Üniversitesi, Ziraat Fakültesi, Tarla Bitkileri Bölümü, Yozgat, TÜRKIYE
}

\begin{tabular}{l}
\hline \multicolumn{1}{c|}{ Geliş Tarihi/Received: 02.05.2020 Kabul Tarihi/Accepted: 30.06 .2020} \\
\hline ORCID ID (Yazar sırasma göre / by author order) \\
\hline (D) orcid.org/0000-0003-3800-7884 (D)orcid.org/0000-0001-6291-3831 (D) orcid.org/0000-0002-5814-5275 \\
\hline (D) orcid.org/0000-0002-9159-1699 (D)orcid.org/0000-0002-6644-5892 \\
*Sorumlu Yazar/Corresponding Author: erdem.gulumser@bilecik.edu.tr
\end{tabular}

"Sorumlu Yazar/Corresponding Author: erdem.gulumser@bilecik.edu.tr

Öz: Ökse otu (Viscum album L.) farklı ağaç ve çalı türlerinin besin maddelerini ve özsuyunu emerek yaşayan asalak bir bitkidir. Bitki Türkiye'de geniş bir alanda yayılım göstermekte ve ruminant hayvanlar için alternatif bir kaba yem kaynağı olarak kullanılmaktadır. Bu çalışmada; yabani armut ve kavak ağaçlarından Temmuz, Ağustos, Aralık ve Ocak aylarında toplanan ökse otunda bazı yem kalite özelliklerinin [ham protein (HP), ham kül (HK), asit deterjanda çözünmeyen lif (ADF), nötral deterjanda çözünmeyen lif (NDF), potasyum $(\mathrm{K})$, fosfor $(\mathrm{P})$, kalsiyum $(\mathrm{Ca})$, magnezyum $(\mathrm{Mg}) \mathrm{ve} \mathrm{Ca} / \mathrm{P}$ oranları] belirlenmesi amaçlanmıştır. Araştırma sonucuna göre en yüksek HP oranı Temmuz ayında armut ağacında (\% 19.45), en düşük ise Ocak ayında yabani armut ağacından (\% 13.28) toplanan ökse otundan elde edilmiştir. Çalışmada ökse otunun HK oranı \% 9.69 (yabani armut + Ocak)-12.90 (yabani armut + Temmuz) arasında değişmiştir. En yüksek ADF ve NDF oranı Aralık ayında armut ağacından toplanan ökse otunda (sırasıyla, \% 31.32, \% 44.40), en düşük ise Temmuz ayında armut ağacından toplanan ökse otundan (sırasıyla, \% 24.10, \% 37.38) elde edilmiştir. Ökse otunun K, P, Ca ve Mg içerikleri sırasıyla $\%$ 2.685-3.857, \% 0.505-0.560, \% 0.968-1.382 ve \% 0.381-580 arasında değişmiştir. Sonuç olarak, Temmuz ayında ve yabani armut ağacından toplanan ökse otunun yem kalitesi açısından daha iyi olduğu tespit edilmiştir. Ayrıca, ökse otunun kalite özellikleri bakımından zengin, dolayısıyla da alternatif kaba yem kaynağı olarak değerlendirilebilmesinin uygun olduğu görülmüştür.

Anahtar Kelimeler: Ökse otu, yabani armut, kavak, kaba yem, ham protein, mineral madde

\section{Determination on Forage Quality of Mistletoe (Viscum album L.)}

\begin{abstract}
Mistletoe (Viscum album L.) is a parasitic plant that lives by absorbing nutrients and sap of various tree and shrub species. The plant has spread over a large area in Turkey, and is an alternative roughage source for ruminant animals. In this study, it was aimed to determine some forage quality traits [crude protein (CP), crude ash (CA), acid detergent fiber (ADF), neutral detergent fiber $(\mathrm{NDF})$, potassium $(\mathrm{K})$, phosphorus $(\mathrm{P})$, calcium $(\mathrm{Ca})$, magnesium $(\mathrm{Mg})$, and $\mathrm{Ca} / \mathrm{P}$ ratios] of mistletoe collected from wild pear and poplar trees in July, August, December, and January. The highest crude protein ratio content was determined from the pear tree in July (19.45\%) and the lowest was from wild pear tree (13.28\%) in January. In the study, the crude ash ratio of mistletoe ranged from $9.69 \%$ (wild pear + January) to 12.90 (wild pear + July). The highest ADF and NDF ratio was determined in the mistletoe collected from the pear tree in December (31.32-44.40\%, respectively), while the lowest was the mistletoe collected from the pear tree in July (24.10-37.38\%, respectively). K, P, Ca and Mg ratios of mistletoe ranged between $2.685-3.857 \%, 0.505-0.560 \%, 0.968-1.382 \%$, and $0.381-580 \%$, respectively. As a result, in the study, it was determined that mistletoe collected in July and from the wild pear tree was better in terms of forage quality. Besides, it was concluded that the mistletoe is rich in terms of forage quality, and therefore it can be evaluated as an alternative source of roughage.
\end{abstract}

Keywords: Mistletoe, wild pear tree, poplar tree, roughage, crude protein, mineral nutrition 


\section{Giriş}

Türkiye'de hayvancılığın gelişmesindeki en önemli engel kaliteli kaba yem açı̆̆ıdır. Acar ve ark. (2020) Türkiye'de 2018 y1lı verilerine göre, 19 milyon BBHB birimi için yıllık 86 milyon ton kaliteli kaba yem gereksiniminin bulunduğunu, karşılanan miktarın 30 milyon, açı̆̆ın ise 56 milyon ton olduğunu bildirmişlerdir. Alçiçek ve ark. (2010) ise Türkiye'de hayvan sayısının fazla olmasina rağmen, dengesiz beslenme nedeniyle verimlerinin oldukça düşük olduğunu bildirmektedirler. $\mathrm{Bu}$ açığın kapatılmasının bir yolu, doğal veya yapay ucuz yem maddelerinin kaba yem kaynağ 1 olarak değerlendirilmelerinin araştırılması ve besin değeri yüksek yemlerin rasyonlara dâhil edilmesidir.

Hayvan beslemede kullanılabilecek ucuz ve doğal yem kaynaklarından bir tanesi de ökse otu (Viscum album L.)'dur. Geleneksel hayvan üretiminin hâkim olduğu bölgelerde ve kaba yem kaynaklarının bulunmadığı dönemlerde, hayvanların ökse otlarını tükettiği bilinmektedir (Gülşen ve Umucalılar, 2007; Madibela, 2009). Ökse otu, tropik ve 1lıman bölgelerde 300-2000 m rakımdaki çeşitli ağaçların ve çalıların üzerinde yarı parazit olarak yaşayan asalak bir türdür. Ökse otu Türkiye'nin hemen hemen her yerinde, özellikle de ormanlık alanlarda çeşitli ağaçların (ahlat, akasya, armut, ayva, badem, erik, kayısı, kiraz, vişne, zerdali, çam, kavak ve köknar) ve çalıların üzerinde yaygın olarak gelişebilmektedir (Çanakçıŏlu, 1993). Düşük miktarda klorofil-protein komplekslerine sahip olmasından (Ahmad ve ark., 2018) dolayı kurak koşullara karşı dayanıklı olup, birçok ağacın dallarında $80 \mathrm{~cm}$ kadar boylanabilmektedir (Boğa ve ark., 2018).

Yapılan araştırmalar, çiftçilerin yeşil yem sıkıntısının olduğu kış aylarında ve kurak yaz dönemlerinde (Haziran-Ağustos) ökse otunu bulunduğu dallardan keserek hayvan beslemede kullandığ1 rapor edilmiştir (Gülşen ve Umucalılar, 2007; Umucalilar ve ark., 2007). Ökse otu, üzerinde yaşadığı ağaçların besin elementleri ve öz suyunu emerek gelişimini devam ettirmektedir. Dolayısıyla, hayvanlar için zengin bir besin kaynağ 1 teşkil etmektedir. Madibela (2009), Viscum türlerinin geviş getiren hayvanların beslenmesinde mineral ve yem kaynağı olabileceğini bildirmiştir. Bitki ayrıca, bazı fenolik bileşikleri içermesi nedeniyle silaj olarak değerlendirilmesi (Sarıçiçek ve ark., 2013) de mümkündür.

$\mathrm{Bu}$ çalışmada, yabani armut ve kavak ağaçlarından toplanan ökse otu ( $V$. album L.)'nun bazı kalite özelliklerinin belirlenmesi amaçlanmıştır.

\section{Materyal veYöntem}

Çalışmanın materyalini, yabani armut ve kavak ağaçlarından toplanan ökse otu ( $V$. album L.) bitkisi teşkil etmiştir. Ökse otu yeşil yem kaynağı sıkıntısının yaşandığı dönemler olan Temmuz, Ağustos, Aralık ve Ocak aylarınında Bilecik ili Merkez ilçesine bağlı Kurt köyündeki yabani armut ve kavak ağaçlarından toplanmıştır (Şekil 1). Ökse otu örnekleri üzerinde yaşadığı bitkilerin meyve gelişim döneminde toplanmıştır.

Ökse otuna ait bitki örneklemesi, daha önce yerleri tespit edilmiş 3 yabani armut ve kavak ağaçları üzerinden ve her ağacın 3 farklı yerinden yapılmıştır. Yaz ve kış aylarına ait her bir dönemde de, bitki örneklerinin toplanması yine aynı ağaçlardan gerçekleştirilmiştir. Toplanan ökse otu örnekleri kese kâğıdına konulduktan sonra, Bilecik Şeyh Edebali Üniversitesi Ziraat ve Doğa Bilimleri Fakültesi Tarla Bitkileri Bölümü Laboratuvarı'na getirilmiştir. Daha sonra bu örnekler etüve konularak $60{ }^{\circ} \mathrm{C}$ 'de sabit ağırlığa gelene kadar kurutulmuş ve $1 \mathrm{~mm}$ çapındaki değirmende ögütülerek analizler için hazır hale getirilmiştir.
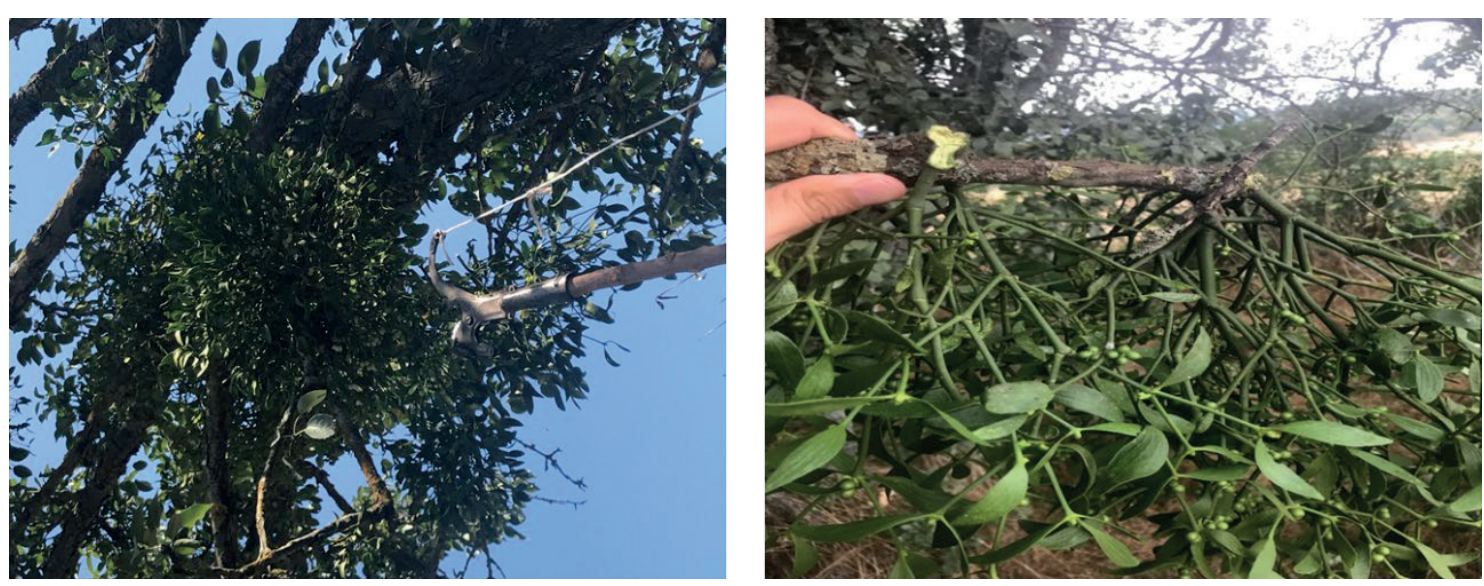

Şekil 1. Ökse otunun toplanması 
Öğütülen ve toz haline getirilen ökse otu örneklerinin azot içerikleri Kjeldahl yöntemi ile belirlenmiş ve bulunan azot değeri 6.25 katsayısı ile çarpılarak ham protein (HP) oranları tespit edilmiştir. Öğütülen örneklerden 2 gram tartılarak yakma firınında $550{ }^{\circ} \mathrm{C}$ 'de 4 saat süreyle yakılmak suretiyle ham kül (HK) oranı hesaplanmıştır (Kacar, 1972). Örneklerin; asit deterjanda çözünmeyen lif (ADF), nötral deterjanda çözünmeyen lif (NDF), potasyum $(\mathrm{K})$, fosfor $(\mathrm{P})$, kalsiyum $(\mathrm{Ca})$ ve magnezyum (Mg) oranları, Yozgat Bozok Üniversitesi Ziraat Fakültesi Tarla Bitkileri Bölümü Laboratuvarı'nda NIRS (Near Infrared Reflektance Spectroscopy-Yakın Kizıl Ötesi Yansıması Spektroskopisi, Foss 6500) cihazıyla IC-0904FE paket programı kullanılarak belirlenmiştir (Straks ve ark., 2004). Çalışmada ayrıca kaba yemlerin önemli kalite parametrelerinden olan $\mathrm{Ca} / \mathrm{P}$ oranı da tespit edilmiştir.

Elde edilen sonuçlar SAS paket programı kullanılarak iki yönlü varyans analizine tabi tutulmuş olup, grup ortalamaları arasındaki farklılıkların karşılaştırılmasında ise Duncan testi kullanılmıştır.

\section{Bulgular ve Tartışma}

Temmuz, Ağustos, Aralık ve Ocak aylarında yabani armut ve kavak ağaçlarından toplanan ökse otu ( $V$. album L.)'nun kuru otunda belirlenen HP ve HK oranlarına ait değerler Tablo 1'de verilmiştir. Ökse otunun içerdiği HP oranı bakımından, ökse otunun toplandı $\breve{g}_{1}$ ağaçlar arasında istatistiksel olarak fark bulunmazken; toplama zamanı arasındaki farklılık ile toplama zamanı $\mathrm{x}$ ağaç türü interaksiyonu çok önemli $(p<0.01)$ olmuştur. Ham kül oranı bakımından ise, ökse otunun toplama zamanı ve ağaçlar arasında istatistiksel olarak fark bulunmazken, toplama zamanı $\mathrm{x}$ ağaç türü interaksiyonu çok önemli $(\mathrm{p}<0.01)$ olmuştur (Tablo $1)$.

İkili interaksiyon incelendiğinde; en yüksek HP oranı Temmuz ayında yabani armut ağacindan (\% 19.45), en düşük ise Ocak ayında yine yabani armut ağacından (\% 13.28) toplanan ökse otundan elde edilmiştir. Temmuz ayında toplanan ökse otunun HP oranı, diğer aylara oranla daha yüksek olurken; yabani armut ve kavak ağaçlarında belirlenen ortalama HP oranları arasinda ise fark olmamıştır. Ağaçların ortalaması olarak en yüksek HP oranı değeri \% 18.57 ile Temmuz ayında toplanan ökse otu örneklerinde tespit edilmiştir (Tablo 1). Temmuz ayında toplanan ökse otunun çiçeklenme döneminde olması nedeniyle protein oranı yüksek çıkmıştır. Balabanlı ve Karadoğan (2009) armut, kavak, badem ve köknar ağaçlarından aldıkları ökse otunun HP oranını sirasıyla \% 14.95, $\% 13.61, \% 13.11$ ve \% 8.94 olarak belirlemişlerdir.

Ham kül oranı değerlendirildiğinde, en yüksek HK oranı Temmuz ayında yabani armut ağacından $\left(\begin{array}{ll}\% & 12.90\end{array}\right)$ ve Ocak ayında kavak ağacından (\% 12.33) toplanan ökse otunda saptanmıştır. Ham kül oranı yönünden en düşük değerler ise HP oranında olduğu gibi Ocak ayında yabani armut ağacından toplanan ökse otu örneklerinde (\% 9.69) belirlenmiştir (Tablo 1). Çalışmada belirlenen HK içeriği (\% 9.69-12.90), Ergun ve Deliorman (1995)'ın farklı ağaçlardan topladıkları ökse otlarının HK içeriğinden (\% 4.99-9.82) daha yüksek bulunmuştur. Bu farklılığın; ökse otunun toplandığ 1 ağaç cinslerinin ve toplama zamanının, iklimin, toprak yapısının ve rakımın farklı olmasindan kaynaklanmış olabileceği düşünülmektedir.

Tablo 1. Ökse otu kuru otunda belirlenen HP ve HK oranları (\%)"

\begin{tabular}{|c|c|c|c|c|c|c|}
\hline \multirow{2}{*}{ Toplama zamanı } & \multicolumn{3}{|c|}{ HP oranı } & \multicolumn{3}{|c|}{ HK oran1 } \\
\hline & Yabani armut & Kavak & Ortalama & Yabani armut & Kavak & Ortalama \\
\hline Temmuz & $19.45 \mathrm{a}$ & $17.70 \mathrm{~b}$ & $18.57 \mathrm{a}$ & $12.90 \mathrm{a}$ & $10.88 \mathrm{bc}$ & 11.89 \\
\hline Ağustos & $17.56 \mathrm{~b}$ & $17.00 \mathrm{~b}$ & $17.28 \mathrm{~b}$ & $10.87 \mathrm{bc}$ & $11.67 \mathrm{ab}$ & 11.27 \\
\hline Aralık & $15.32 \mathrm{c}$ & $14.00 \mathrm{~cd}$ & $14.66 \mathrm{c}$ & $11.88 \mathrm{ab}$ & $10.98 \mathrm{~b}$ & 11.43 \\
\hline Ocak & $13.28 \mathrm{~d}$ & $14.92 \mathrm{c}$ & $14.10 \mathrm{c}$ & $9.69 \mathrm{c}$ & $12.33 \mathrm{a}$ & 11.01 \\
\hline Ortalama & 16.40 & 15.90 & & 11.33 & 11.47 & \\
\hline
\end{tabular}

*: Aynı grupta aynı harfle gösterilen ortalamalar arasındaki farklılık istatistiki açıdan önemli değildir.

Araştırmada ökse otu kuru otunun içerdiği ADF ve NDF oranları bakımından toplama zamanı ve ağaçlar arasındaki farklılık ile toplama zamanı $\mathrm{x}$ ağaç türü interaksiyonu istatistiksel olarak çok önemli $(p<0.01)$ olmuştur. En düşük ADF ve NDF oranı Temmuz ayında yabani armut ağacından toplanan ökse otunda (sirasiyla $\% \quad 24.10$ ve \% 37.38) belirlenmiştir (Tablo 2).
Yem kalitesi, yemin içindeki lif miktarına ve oranına bağlıdır. Zira yemde lif miktarı ve oranı ne kadar fazla ise sindirilebilirlik o kadar güçleşmektedir. ADF, bitkinin sindirilebilirliğinin, NDF ise hayvanlar tarafından alınabilirliğinin bir göstergesidir. $\mathrm{Bu}$ itibarla yemlerde ADF oranının $\% 30$ ve altında, NDF oranının ise $\% 40$ ve altında bir değer olması istenilmektedir (Ateş, 2012). 
Tablo 2. Ökse otu kuru otunda belirlenen ADF ve NDF oranları (\%)

\begin{tabular}{|c|c|c|c|c|c|c|}
\hline \multirow{2}{*}{ Toplama zaman 1} & \multicolumn{3}{|c|}{ ADF oran1 } & \multicolumn{3}{|c|}{ NDF oran1 } \\
\hline & Yabani armut & Kavak & Ortalama & Yabani armut & Kavak & Ortalama \\
\hline Temmuz & $24.10 \mathrm{f}$ & $27.15 \mathrm{bcd}$ & $25.62 \mathrm{c}$ & $37.38 \mathrm{~d}$ & $41.82 \mathrm{bc}$ & $39.60 \mathrm{~d}$ \\
\hline Ağustos & $27.70 \mathrm{bc}$ & $24.74 \mathrm{ef}$ & $26.22 \mathrm{~b}$ & $42.60 \mathrm{~b}$ & $40.71 \mathrm{c}$ & $41.65 \mathrm{c}$ \\
\hline Aralık & $31.32 \mathrm{a}$ & $25.56 \mathrm{def}$ & $28.44 \mathrm{a}$ & $44.40 \mathrm{a}$ & $41.58 \mathrm{bc}$ & $42.99 \mathrm{ab}$ \\
\hline Ocak & $28.28 \mathrm{~b}$ & $26.10 \mathrm{cde}$ & $27.19 \mathrm{~b}$ & $43.35 \mathrm{ab}$ & $41.67 \mathrm{bc}$ & $42.51 \mathrm{~b}$ \\
\hline Ortalama & $31.17 \mathrm{~A}$ & $25.88 \mathrm{~B}$ & & $41.67 \mathrm{~A}$ & $41.45 \mathrm{~B}$ & \\
\hline
\end{tabular}

*: Aynı grupta aynı harfle gösterilen ortalamalar arasındaki farklılık istatistiki açıdan önemli değildir.

Çalıșmada yabani armut ağacından Temmuz ayında toplanan ökse otunun ADF ve NDF oranlarının istenen değerler arasında olduğu tespit edilmiştir. Ökse otunun toplandığı ağaçların ortalaması olarak en düşük ADF ve NDF oranı değerleri sırasıyla $\% 25.62$ ve \% 39.60 ile Temmuz ayında toplanan bitki örneklerinde belirlenmiştir (Tablo 2).

Yabani armut ve kavak ağaçlarından, Temmuz, Ağustos, Aralık ve Ocak aylarında toplanan ökse otuna ait $\mathrm{K}$ ve $\mathrm{P}$ oranları Tablo 3'te verilmiştir. Çalışmada, ökse otunun toplandığı ağaçlar arasında sadece $K$ yönünden önemli $(\mathrm{p}<0.05)$ farkl1lık tespit edilirken; toplama zamanı arasındaki farklılık hem $\mathrm{K}$ hem de $\mathrm{P}$ yönünden çok önemli $(\mathrm{p}<0.01)$ olmuştur. Buna göre, kavak ağaçlarından toplanan ökse otunun ortalama K oranı (\% 3.700) yabani armut ağacından toplanan ökse otunun ortalama $\mathrm{K}$ oranından (\% 3.301) daha yüksek olmuştur. Toplama zamanları incelendiğinde, ökse otu kuru otunun içerdiği en yüksek $\mathrm{K}$ oranı ağaçların ortalaması olarak \% 3.806 ile Temmuz ayında toplanan örneklerde belirlenmiş, Ağustos ayında toplanan ökse otu örnekleri ile aralarındaki farklılık istatistiksel anlamda önemsiz bulunmuştur. Fosfor yönünden ise Temmuz ( $\%$ 0.552), Ağustos $(\% \quad 0.544)$ ve Ocak (\% 0.548$)$ aylarında toplanan ökse otunun $\mathrm{P}$ oranları aynı istatistiksel grupta yer almış ve Aralık ayında toplanan ökse otu değerlerinden istatistiki olarak anlamlı bir şekilde daha yüksek olmuştur (Tablo 3).

Değişik ağaçlardan toplanan ökse otunun $\mathrm{Ca}$ ve $\mathrm{Mg}$ oranları bakımından toplama zamanı ve ağaç türleri arasındaki farklılık istatistiksel olarak çok önemli $(\mathrm{p}<0.01)$ olmuş; her iki özellik yönünden de ikili interaksiyon anlamlı $(\mathrm{p}<0.01)$ bulunmuştur. Kalsiyum oranı \% 0.965 (kavak + Aralık ayı) ile $\% \quad 1.382$ (yabani armut + Ocak ayı) arasında değişmiştir. Ağaçlar arasında yabani armut üzerinde gelişen ökse otu \% 1.250 ile kavak üzerinde gelişen ökse otuna göre daha yüksek (\% 1.119) Ca oranına sahip olmuştur. Toplama zamanları değerlendirildiğinde ise, aynı istatistiksel grupta yer alan Aralık ve Ocak ayları Temmuz ve Ağustos aylarına göre daha yüksek Ca oranına sahip olmuştur (Tablo 4).

Ökse otu kuru otunun $\mathrm{Mg}$ oranları, toplama zamanı ve üzerinde yetiştiği ağaç yönünden incelendiğinde; en yüksek $\mathrm{Mg}$ oranı \% 0.580 (yabani armut + Ocak ay1), en düşük ise \% 0.381 (kavak + Ağustos ayı) olarak tespit edilmiştir. Ağaçlar arasında yabani armut üzerinde gelişen ökse otu (\% 0.491), kavak ağacı üzerinde gelişen ökse otuna (\% 0.443$)$ göre; toplama zamanları arasında ise Ocak ayında toplanan ökse otu (\% 0.553) diğer aylarda toplanan ökse otuna göre daha yüksek Mg oranına sahip olmuştur (Tablo 4).

Tablo 3. Ökse otu kuru otunda belirlenen K ve P oranları (\%)*

\begin{tabular}{lcccccc}
\hline \multirow{2}{*}{ Toplama zamanı } & \multicolumn{3}{c}{ K oranı } & \multicolumn{3}{c}{ P oran1 } \\
\cline { 2 - 7 } & Yabani armut & Kavak & Ortalama & Yabani armut & Kavak & Ortalama \\
\hline Temmuz & 3.756 & 3.857 & $3.806 \mathrm{a}$ & 0.554 & 0.551 & $0.552 \mathrm{a}$ \\
A ğustos & 3.489 & 3.632 & $3.560 \mathrm{ab}$ & 0.541 & 0.546 & $0.544 \mathrm{a}$ \\
Aralık & 3.274 & 3.565 & $3.419 \mathrm{~b}$ & 0.533 & 0.505 & $0.519 \mathrm{~b}$ \\
Ocak & 2.685 & 3.749 & $3.217 \mathrm{~b}$ & 0.536 & 0.560 & $0.548 \mathrm{a}$ \\
\hline Ortalama & $3.301 \mathrm{~B}$ & $3.700 \mathrm{~A}$ & & 0.541 & 0.541 \\
\hline
\end{tabular}

*: Aynı grupta aynı harfle gösterilen ortalamalar arasındaki farklılık istatistiki açıdan önemli değildir.

Tablo 4. Ökse otu kuru otunda belirlenen Ca ve Mg oranları (\%)

\begin{tabular}{lcccccc}
\hline \multirow{2}{*}{ Toplama zamanı } & \multicolumn{3}{c}{ Ca oranı } & \multicolumn{3}{c}{ Mg oran1 } \\
\cline { 2 - 6 } & Yabani armut & Kavak & Ortalama & Yabani armut & Kavak & Ortalama \\
\hline Temmuz & $1.337 \mathrm{a}$ & $0.972 \mathrm{c}$ & $1.155 \mathrm{~b}$ & $0.446 \mathrm{de}$ & $0.411 \mathrm{ef}$ & $0.429 \mathrm{c}$ \\
Ağustos & $1.134 \mathrm{~b}$ & $0.965 \mathrm{c}$ & $1.050 \mathrm{c}$ & $0.445 \mathrm{de}$ & $0.381 \mathrm{f}$ & $0.413 \mathrm{c}$ \\
Aralık & $1.145 \mathrm{~b}$ & $1.183 \mathrm{~b}$ & $1.164 \mathrm{a}$ & $0.493 \mathrm{bc}$ & $0.456 \mathrm{bc}$ & $0.475 \mathrm{~b}$ \\
Ocak & $1.382 \mathrm{a}$ & $1.354 \mathrm{a}$ & $1.368 \mathrm{a}$ & $0.580 \mathrm{a}$ & $0.525 \mathrm{~b}$ & $0.553 \mathrm{a}$ \\
\hline Ortalama & $1.250 \mathrm{~A}$ & $1.119 \mathrm{~B}$ & & $0.491 \mathrm{~A}$ & $0.443 \mathrm{~B}$ \\
\hline
\end{tabular}

${ }^{*}:$ Aynı grupta aynı harfle gösterilen ortalamalar arasındaki farklılık istatistiki açıdan önemli değildir. 
Hayvanlar için gerekli olan makro besin elementlerinin başında $\mathrm{K}, \mathrm{P}, \mathrm{Ca}$ ve $\mathrm{Mg}$ gelmekte ve adı geçen bu besin maddeleri kaba yemlerin kalitesini etkilemektedir (Özyazıcı ve Açıkbaş, 2019). Bu elementlerin ruminant hayvanlar için de çok farklı fonksiyonları vardır. Fosfor hayvanların iskelet yapısında ve döl veriminde etkili olurken (Dua ve Care, 1999); Ca ve Mg hayvanların kemik ve diş dokusunun gelişimininde rol oynamakta, $\mathrm{Ca}$ aynı zamanda süt veriminde de etkili olmakta, $\mathrm{K}$ ise vücudun asit-baz dengesini sağlamaktadır (Başbağ ve ark., 2011; Gürsoy ve Macit, 2017). Bu itibarla hayvanların makro besin elementi ihtiyacının karşılanması için kaba yemlerde K oranının \% 0.8 , $\mathrm{P}$ oranının \% $0.21, \mathrm{Ca}$ oranının $\% 0.3$ ve $\mathrm{Mg}$ oranının $\% \quad 0.1$ olması gerektiği bildirilmiştir (Kidambi ve ark., 1989). Literatürdeki bu sinır değerler dikkate alındığında, çalışmada ökse otu kuru otunda belirlenen $\mathrm{K}, \mathrm{P}, \mathrm{Ca}$ ve $\mathrm{Mg}$ değerlerinin yem rasyonlarında istenen düzeyin üzerinde olduğu görülmüştür.

Yem bitkilerinin içermiş oldukları besin değerlerinin yanında, besin elementleri arasındaki oran da önemlidir. $\mathrm{Bu}$ oranların başında $\mathrm{Ca} / \mathrm{P}$ oranı gelmekte; bu oranın hayvan yeminde $2 / 1$ şeklinde olmasi tercih edilmektedir. Fidan (2006) $\mathrm{Ca} / \mathrm{P}$ oranının vücutta yaklaşık olarak $2 / 1$ seklinde olmasinın rasyonda da benzer bir oranın tercih edilmesinin asıl sebebi olduğunu bildirmektedir. $\mathrm{Bu}$ oran 2'nin üzerine çıkarsa hayvanlarda süt humması (doğum felci) görülmektedir (Açıkgöz, 2001). Ancak hayvanların rasyonuna yeterli miktarda fosfor ve D vitamini ilave edildiği takdirde, bu oran 8/1'e kadar tolere edilebilmektedir (Fidan, 2006). Dolaysıyla, rasyonun $\mathrm{Ca} / \mathrm{P}$ oranından daha ziyade, hayvanların $\mathrm{Ca}, \mathrm{P}$ ve $\mathrm{D}$ vitamini ihtiyaçlarının karşılanması daha önemlidir (Tuncer, 1997). Çalıșmada ökse otlarında belirlenen $\mathrm{Ca} / \mathrm{P}$ oranı \% 1.76-2.58 arasında değişmiş ve tüm işlemler kritik seviyenin (8/1) altında olmuştur. Yabani armut ağacından toplanan ökse otlarının ortalama $\mathrm{Ca} / \mathrm{P}$ oran $1 \% 2.30$, kavak ağacından toplanan ökse otlarının ise \% 2.07 olarak belirlenmiştir. Ayrıca Ocak ayında belirlenen $\mathrm{Ca} / \mathrm{P}$ oranı \% 2.50 ile diğer aylardan daha yüksek olmuştur (Şekil 2).

\section{Sonuçlar}

Ökse otu üzerinde yaşadığı ağaç türlerinin besin maddeleri ile suyunu alarak gelişimlerini engeller ve zamanla zayıf düşürerek kurumasına neden olur. Diğer taraftan ökse otu, ruminant hayvanlar için alternatif kaba yem olarak kullanılmaktadır.

Temmuz, Ağustos, Aralık ve Ocak aylarında yabani armut ve kavak ağaçlarından toplanan ökse otu $(V$. album L.)'nun kaba yem olarak değerlendirilmesinde bazı kalite parametrelerinin incelendiği bu çalışmada; Temmuz ayında ve yabani armut ağacından toplanan ökse otunun yem kalitesi açısından daha iyi olduğu tespit edilmiştir. Çalışmada ayrıca, bitkinin içermiş olduğu ham protein oranı ile besin madde kompozisyonu bakımından zengin ve sindirilebilirliğinin ise yüksek olduğu, dolaysıyla da alternatif kaba yem kaynağı olarak değerlendirilebilmesinin mümkün olduğu sonucuna varılmıştır.

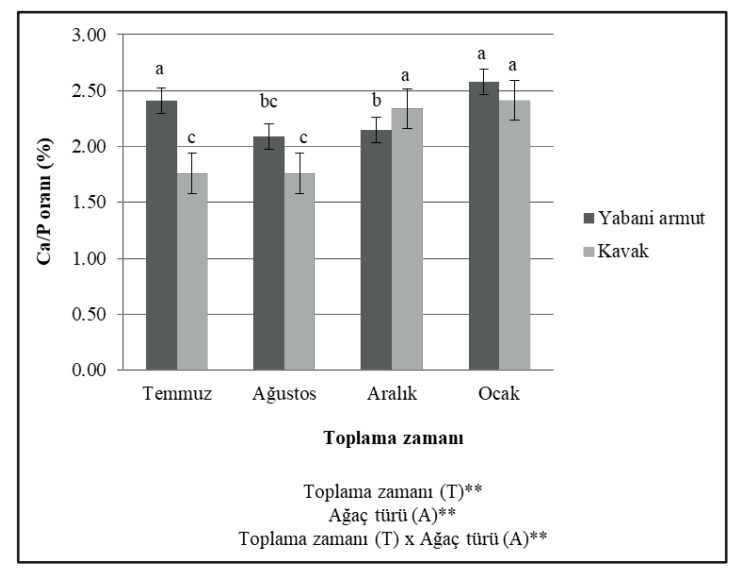

Şekil 2. Ökse otunun $\mathrm{Ca} / \mathrm{P}$ oranı

\section{Teşekkür}

Bu çalışma; Türkiye Bilimsel ve Teknolojik Araştırma Kurumu (TÜBİTAK) tarafından "2209A Üniversite Öğrencileri Araştırma Projeleri Destekleme Programı" kapsamında “1919B011800989” no'lu proje ile desteklenmiştir.

\section{Kaynaklar}

Acar, Z., Tan, M., Ayan, İ., Önal Aşçı, Ö., Mut, H., Başaran, U., Gülümser, E., Can, M., Kaymak, G., 2020. Türkiye'de yem bitkileri tarımının durumu ve geliștirme olanakları. Türkiye Ziraat Mühendisleri IX. Teknik Kongresi, Bildiriler Kitabı, 13-17 Ocak, Ankara, s. 529-553.

Açıkgöz, E., 2001. Yem Bitkileri. Uludağ Üniversitesi Güçlendirme Vakfı Yayınları, Genel Yayın No: 182, Bursa.

Ahmad, S., Mir, N.H., Sultan, S.M., 2018. White-berry mistletoe (Viscum album L.): A hemiparasitic plant: Occurrence and ethnobotanical use in Kashmir. Journal of Pharmacognosy and Phytochemistry, 7(1): 1831-1833.

Alçiçek, A., Kılıç, A., Ayhan, V., Özdoğan, M., 2010. Türkiye'de kaba yem üretimi ve sorunlar1. Ziraat Mühendisliği VII. Teknik Kongresi, Bildiriler Kitabı, 11-15 Ocak, Ankara, s. 1071-1080.

Ateş, E., 2012. The mineral, amino acid and fiber contents and forage yield of pea (Pisum arvense L.), fiddleneck (Phacelie tanacetifolia Benth.) and their mixtures under dry land conditions in the Western Turkey. Romanian Agricultural Research, (29): 237 244. 
Balabanlı, C., Karadoğan, T., 2009. Ökse otunun hayvan yemi olarak değerlendirme imkanları. Selçuk Üniversitesi Ziraat Fakültesi Dergisi, 13: 101-106.

Başbağ, M., Çaçan, E., Sayar, M.S., 2011. Güneydoğu Anadolu Bölgesi doğal alanlarından toplanan bazı fiğ türlerinin ot kalitesi özelliklerinin belirlenmesi. Uluslararası Katılımlı I. Ali Numan Kirac Tarım Kongresi ve Fuar, Bildiriler Kitab1, 27-30 Nisan, Eskişehir, s. 143-151.

Boğa, M., Yaman, S., Canoğlu, D., Burğut, A., 2018. Niğde bölgesinde bulunan ökse otunun yem değerinin in vitro gaz üretim yöntemi ile belirlenmesi. Türk Tarım-Gida Bilim ve Teknoloji Dergisi, 6(8): 10511057.

Çanakçığlu, H., 1993. Orman Koruma. İstanbul Üniversitesi, Orman Fakültesi Yayınları, Genel Yayın. No: 411, İstanbul.

Dua, K., Care, A.D., 1999. The role of phosphate on the rates of mineral absorbtion from the forestomatch of sheep. The Veterinary Journal, 157: 51-55.

Ergun, F., Deliorman, D., 1995. Farklı konakçılardaki Viscum album L. örneklerinin etken maddeleri yönünden incelenmesi. Ankara Eczacılık Fakültesi Dergisi, 24(2): 127-139.

Fidan, H., 2006. Sığırların serumlarındaki bazı element düzeyleri üzerine mevsimsel değişimlerin etkisi. Yüksek lisans tezi, Adnan Menderes Üniversitesi Sağlık Bilimleri Enstitüsü, Aydın.

Gülșen, N., Umucalılar, H.D., 2007. Toros Göknarı ökse otunun besleyici değerinin "in sütu" ve "in vitro" yöntemlerle tespiti. Hayvancılık Araştırma Dergisi, 17(1): 6-13.

Gürsoy, E., Macit, E., 2017. Erzurum ili çayır ve meralarında doğal olarak yetişen bazı baklagil ve buğdaygil yem bitkilerinin mineral madde kompozisyonlarının belirlenmesi. Alınteri Journal of Agricultural Sciences, 32(1): 1-9.
Kacar, B., 1972. Bitki ve Toprağın Kimyasal Analizleri, II. Bitki Analizleri. Atatürk Üniversitesi, Ziraat Fakültesi Yayınları, Erzurum.

Kidambi, S.P., Matches, A.G., Gricgs, T.C., 1989. Variability for $\mathrm{Ca}, \mathrm{Mg}, \mathrm{K}, \mathrm{Cu}, \mathrm{Zn}$ and $\mathrm{K} /(\mathrm{Ca}+\mathrm{Mg})$ ratio among 3 wheat grasses and sainfoin on the southern high plains. Journal of Range Management, 42: 316-322.

Madibela, O., 2009. Chemical composition and in vitro dry matter digestibilt of four parasitic plants (Tapinanthus lugardii, Erianthenum ngamicum, Viscum rotindifolium, Viscum verrucosum) in Botswana. Animal Feed Science and Technology, 84(1): 97-106.

Özyazıcı, M.A., Açıkbaş, S., 2019. Kaba yemlerin fosfor, potasyum, kalsiyum ve magnezyum içeriği ve hayvan beslemedeki önemleri. ISPEC-International Conference on Agriculture, Animal Science and Rural Development-III, December 20-22, Van, Turkey, pp. 553-568.

Sarıçiçek, Z, Fatma, A., 2013. Farklı konakçılara ait ökse otları (Viscum album L.)'nın silaj kalitesinin belirlenmesi üzerine bir araştırma. 8. Ulusal Zootekni Bilim Kongresi, Bildiriler Kitabı, 5-7 Eylül, Çanakkale.

Straks, P.J., Samuel, W.C., William, A.P., 2004. Determination of forage chemical composition using remote sensing. Journal of Range Management, 57: 635-640.

Tuncer, S.D., 1997. Sığır Besleme. Medisan Yayın Serisi, No: 31 , Ankara.

Umucalılar, H.D., Gülşen, N., Coşkun, B., Hayirli, A., Dural, H., 2007. Nutrient composition of mistletoe (Viscum album) and its nutritive value for ruminant animals. Agroforestry Systems, 71: 77-87. 